\title{
As múltiplas faces de um roteiro: O piano
}

\author{
Leila Darin*
}

\begin{abstract}
Above all, we need to be less concerned with inchoate notions of "fidelity" and to give more attention to dialogical responses - to readings, critiques, interpretations, and rewritings of prior material. If we can do all these things, we will produce a criticism that not only takes into account, but also welcomes, the differences among the media (Robert Stam, Beyond Fidelity)
\end{abstract}

Quando o semioticista russo Roman Jakobson cunhou o termo "tradução intersemiótica" para referir-se à tradução "de um sistema de signos para outro, por exemplo, da arte verbal para a música, a dança, o cinema e a pintura" (1969, p.72) abriu um campo extenso de debate sobre a relação entre linguagens. Estudiosos como J. Plaza (1987), B. MacFarlane (1996) e G. Bluestone (2003), dentre outros, contribuíram para o tema acrescentando e enfatizando novos aspectos: o trabalho criativo entre os diferentes sistemas sígnicos, a relação entre as narrativas literárias e fílmicas, a rejeição da noção tradicional de fidelidade como critério de qualidade, a problematização dos limites entre os processos de tradução e adaptação.

Os estudos sobre as relações entre sistemas sígnicos se adensaram a partir de perspectivas igualmente produtivas advindas da irrigação fecunda entre as áreas de cinema, música, literatura, teatro, arquitetura, pintura, dança, fotografia, desenho, dentre outras - gerando um olhar renovado para os fenômenos entre artes, entre meios, ou intermídia. Conceito discutido, entre outros, por Dick Higgins, Claus Cüver, Irina Rajewsky, o termo intermidialidade diz respeito à fusão, à sobreposição ou ao cruzamento de diferentes campos de estudo como a literatura, a música, as artes visuais, a filosofia, diversas ciências sociais, entre outros" (Holderbaum, 2014, p. 80).

* Pontifícia Universidade Católica de São Paulo. 
Interessa-nos aqui salientar uma categoria específica de intermidialidade proposta por Rajewsky (2010), dada sua proximidade com a ideia de tradução intersemiótica: a transposição midiática. Segundo a teórica, a transposição midiática está orientada ao processo de produção:

\footnotetext{
Nesse caso, a qualidade intermidiática - o critério de cruzamento de fronteiras midiáticas - relaciona-se à maneira com que uma configuração midiática vem ao mundo, ou seja, relaciona-se à transformação de uma configuração midiática definida (um texto, um filme, etc...) ou de seu substrato noutra mídia. O texto ou filme 'original' constitui a 'fonte' da recémformada configuração midiática, cuja formação baseia-se num processo obrigatório de transformação intermidiática específico a uma mídia. (Rajewsky, 2012, p. 58-9)
}

A referência a uma configuração midiática "fonte" (texto de partida) que se transforma, por meio de um processo obrigatório específico, em outra configuração midiática (texto de chegada), nos remete ao processo de adaptação entre mídias, ou entre artes; e, no caso de que trataremos neste artigo, do processo de recriação de um filme e de um romance a partir de um roteiro.

Autor de vários trabalhos sobre mídia e cinema, o teórico norteamericano de origem holandesa Robert Stam discute a relação entre artes, em especial a adaptação do texto literário para o texto fílmico. Em "Beyond Fidelity" (2000), o autor questiona a forma moralista como a crítica especializada, de modo geral, trata as adaptações cinematográficas relativamente às obras literárias que as inspiram - a tendência é que as adaptações sejam avaliadas sob a ótica da traição, da infidelidade, da deformação e da vulgarização. Por detrás da visão dos críticos, argumenta Stam, encontra-se o pressuposto de que a obra literária traz em si uma "essência", que deve ser preservada na obra fílmica.

Para refutar o critério da fidelidade à essência como sucesso de uma adaptação, Stam defende o respeito às idiossincrasias, aos potenciais e limites das diferentes mídias a partir de dois conceitos fundamentais, propostos pelo filósofo da linguagem Mikhail Bakhtin: a intertextualidade e o dialogismo. 
Com base nesses pressupostos, o teórico americano concebe toda adaptação como uma releitura/reescrita constituída de uma amálgama de práticas discursivas, com ou sem origem conhecida, advindas de uma ou mais culturas e períodos históricos, que dialogam no interior do texto artístico, também ele produto criativo do intercâmbio de materiais das mais diversas procedências. Nas palavras de Stam, “Em termos históricos e de gênero, tanto o romance quanto o filme têm consistentemente canibalizado gêneros e mídias antecedentes" (Stam, 2008, p. 24). Concebidas como (re)escritas, versões críticas e atos criativos, as adaptações cinematográficas não podem mais ser submetidas ao critério da "fidelidade" como parâmetro de avaliação. A discussão empreendida por Stam nos permite entender a adaptação fílmica de uma obra literária como um processo de transposição midiática, nos termos de Rajewsky.

Para elaborar a questão relativa ao tipo de vínculo que se estabelece entre uma configuração midiática de partida e sua reconfiguração por meio de outra mídia, Stam (2000) recorre às cinco categorias de relações transtextuais postuladas por Gerard Genette em Palimpsestes (1982), destacando a relevância da "hipertextualidade" para a adaptação, embora o estudo de Genette não trate da arte cinematográfica. O teórico americano considera a obra preexistente em uma mídia como hipotexto, a partir do qual será gerada uma obra em outra mídia, ou um hipertexto. No caso das adaptações cinematográficas, elas são "hipertextos derivados de hipotextos préexistentes que foram transformados por operações de seleção, amplificação, concretização e efetivação" (Stam, 2006, p. 33). As diversas adaptações fílmicas de um romance são elaborações hipertextuais, e seu número pode ser lido como sinal do status canônico do hipotexto.

O teórico norte-americano postula que as adaptações alimentam o "dialogismo intertextual" (2000, p. 64), processo que irriga continuamente o campo das práticas discursivas de uma cultura, gerando uma intricada rede de composições textuais. Marcel Amorim (2013), pesquisador sobre o tema, deixa claro que Stam dá ao conceito de dialogismo intertextual um caráter de amplo alcance: 


\begin{abstract}
Mais amplamente falando, o conceito defendido pelo autor se refere às possibilidades infinitas de disseminação geradas por todas as práticas discursivas de uma cultura, ou seja, à matriz comunicativa de enunciados dentro dos quais o texto artístico é situado e que o alcançam não somente por meio de influências perceptíveis - intertextos -, mas também por meio de um processo sutil de disseminação discursiva - a dialogicidade. (AMORIM 2013, p. 21)
\end{abstract}

Como prática de reescrita intertextual ou transposição midiática, a adaptação oferece a leitores, espectadores e observadores uma nova face do texto de partida.

\title{
Hipertextos
}

Considerado um dos expoentes do cinema da década de 1990, The Piano, ou O Piano, é um filme áustralo-franco-neozelandês de 1993, escrito e dirigido por Jane Campion. Em 1993, foi premiado com a Palma de Ouro do Festival de Cinema de Cannes; em 1994, Campion recebeu o Oscar de Melhor Roteiro Original, Holly Hunter o de Melhor Atriz e Ann Paquin de Melhor Atriz Coadjuvante.

Dentre os muitos aspectos que tornam o filme um sucesso, tanto de crítica quanto de público, e que lhe rendeu visibilidade internacional, destaca-se a originalidade do roteiro da neozelandesa Jane Campion, que produziu um roteiro para o filme em 1991, o qual posteriormente foi reescrito como romance em coautoria com a romancista canadense Kate Pullinger (1994). O roteiro de 1991 pode ser encontrado no endereço http://www.dailyscript.com/scripts/thepianolesson.html.

Neste caso, portanto, o filme e o romance são adaptações ou hipertextos derivados do hipotexto roteiro, intitulado The Piano Lesson. Com o intuito de contribuir para a reflexão sobre o processo de tradução/adaptação/transformação intermediática, passamos a discutir, a seguir, as relações entre as duas produções hipertextuais: a escrita (O piano, na tradução publicada pela Ed.Rocco, em 1994) e a fílmica (O Piano, 1993). 


\section{Narrativas paralelas}

Em Novel to Film (1996), o teórico McFarlane apresenta uma proposta cujo foco é a centralidade da estrutura narrativa, que, analisada em termos de transferência intersemiótica, consiste basicamente em dois elementos: os que podem ser facilmente transferidos do texto para o cinema e aqueles que requerem maior criatividade para que possam ser transpostos (1996 apud AMORIM, 2013, p. 19). Sob essa perspectiva, é possível observar que tanto o romance como o filme $O$ Piano seguem um fio condutor quanto à estrutura da narrativa, isto é, apresentam uma sequência semelhante de ações que constituem, por assim dizer, o "esqueleto" da história - o que não equivale a dizer que são "fieis ao roteiro", mas que se aproximam da estrutura narrativa por meio de mídias diferentes que possuem suas próprias formas de narrar.

Em poucas palavras, Campion retrata a trajetória de Ada McGrath, uma mulher que não fala desde os seis anos e que deixa a Escócia com sua filha Flora rumo à Nova Zelândia para conhecer e casar-se com o inglês Stewart, com quem seu pai fizera um acordo matrimonial. Após meses de viagem exaustiva por mar, Ada e Flora desembarcam em uma praia selvagem, com seus pertences e um piano envolto em tábuas, instrumento que é parte integrante da vida da protagonista.

A história ocorre no século XIX, em Aotearoa (Nova Zelândia, na língua maori), isto é, em um território ainda parcialmente colonizado pelos ingleses. Incapaz de compreender a importância da música para Ada e sua relação de quase exclusividade com sua filha, que atua como sua intérprete da língua de sinais, Stewart não logra conquistar a simpatia ou despertar o desejo de Ada. Quem terá êxito na conquista será o administrador inglês Baines, homem muito mais próximo da cultura maori, que respeita e admira o elo de Ada com a música. As aulas de piano que Baines "negocia" por uma porção de terra levam ao contato e à paixão entre eles.

Sentindo-se relegada a segundo plano, Flora fala do romance a Stewart, que se vinga, cortando com um machado um dos dedos da mão de Ada. Frustrado com a situação, Stewart deixa que Ada vá ao encontro de Baines. O casal e Flora partem em uma canoa, levando consigo o piano; mas, seu peso é demasiado e a pianista concorda em atirá-lo ao mar. Pro- 
positadamente, Ada deixa que seu pé se prenda à corda que une o piano à embarcação (espécie de cordão umbilical) e ambos submergem no oceano profundo. Porém, Ada escolhe viver.

\section{Mídia: a palavra}

Considerando o roteiro The Piano Lesson (1991) como hipotexto, e o romance O Piano (1994) como hipertexto dele decorrente, gostaríamos de argumentar que o hipertexto pode ser entendido como um romance "protocinematográfico" - conceito que Robert Stam utiliza ao analisar Madame Bovary, de Flaubert:

\footnotetext{
Esta qualidade ['protocinematográfico'] opera em vários aspectos. Primeiro, o romance [Madame Bovary] apresenta uma precisão semelhante à de um roteiro cinematográfico no que concerne a descrição de gestos e atitudes [...] só faltam as indicações técnicas como crane shot ou dolly in. Flaubert dá dicas sensoriais e composicionais para possíveis futuros adaptadores [...]. (STAM, 2008, pp. 198-199)
}

A definição de um romance como "protocinematográfico" evidencia o caráter híbrido do texto narrativo, que transita por duas (ou mais) mídias, remetendo a uma das "subcategorias" de intermidialidade propostas por Rajewsky: a combinação de mídias. Esse tipo de intermidialidade "inclui fenômenos como ópera, filme, teatro, manuscritos iluminados/iluminuras, instalações computadorizadas ou Sound Art, história em quadrinhos ou, noutra terminologia, as chamadas formas multimídia, de mescla de mídias e intermidiáticas" (Rajewsky, 2012, p. 58). Isto quer dizer que além de o romance, como toda mídia verbal, estar construído com base em textos culturais, literários e históricos pré-existentes — ou "referências intermidiáticas", no dizer de Rajewsky - ele traz traços de uma linguagem protocinematográfica, possivelmente decorrente do contato com o roteiro, seu texto de partida. Em O Piano, é possível localizar passagens que se assemelham às descrições precisas e bem delineadas de comportamentos, ações e pontos de vista que Stam destaca em trechos do romance de Flaubert. Vejamos, a título de exemplo, o relato do episódio que ocorre à mesa de jantar quando Ada tinha seis anos, e que acabará por emudecê-la pelo resto da vida. Seu 
pai, Wyston McGrath, havia convidado, a contragosto, as tias solteironas Patrícia e Ethel para visitá-los.

\begin{abstract}
A pequena Ada foi instalada entre suas duas tias solteironas, numa cadeira alta feita especialmente para ela. $\mathrm{O}$ jantar não estava correndo bem. McGrath não gostara do assado, declarando-o, para quem quisesse ouvir, duro e intragável. Insistiu em devolvê-lo à cozinha, parecendo não se aperceber de que haveria nada para substituí-lo, caso isso acontecesse. Os hóspedes, privados de seus pratos, mal conseguiam esconder o desapontamento, mas contornaram a situação tecendo comentários generosos para o anfitrião e sua filha. Foi no intervalo entre o momento em que a refeição foi retirada da mesa e a chegada da sobremesa que a atenção dos hóspedes e de McGrath voltou-se para Ada, que se divertia despejando todo o conteúdo do açucareiro num respeitável monte de grânulos brancos, que depois era esfregado na madeira escura da mesa para, logo em seguida, receber um ágil dedinho molhado, encarregado de traçar o nome da artista. (Campion; Pullinger, 1994, p. 22)
\end{abstract}

A cena é apresentada como uma sequência detalhada de ações e reações, estimulando no leitor a visualização e recriação do cenário, das personagens e de sua posição à mesa, das expressões faciais, dos gestos e da crescente tensão emocional. Fechada em seu quarto, a resposta de Ada não foi o choro:

\footnotetext{
Durante algum tempo, ela permaneceu sentada, as mãos apertadas com força no colo, enquanto os olhos, grandes, negros e gélidos, concentravam-se além, na parede em frente. A criança ficou assim, olhando o nada, sem se mover, sentindo o quarto à volta dela escorregando lentamente para as sombras, a noite fechada. (1994, p. 24)
}

Nesta passagem, como em inúmeras outras, são fornecidas informações sobre o posicionamento da personagem na cena e sugestões sobre o ângulo de filmagem, que deve acompanhar o lento desmoronamento interno que a levará ao silêncio. Assim se delineia o embrião de um dos atributos marcantes da personalidade de Ada: a força de sua determinação e de seu desejo.

Outro recurso recorrente no relato, também associado ao romance protocinematográfico, é a alusão às cores para sinalizar o elo entre o mundo ex- 
terno e o interno: "O sol declinava e com isso aumentava em Ada a percepção do perigo que corriam. À luz verde azulada, ela e Flora correram pela extensão da areia [...] só restava do sol uma nesga rosada no céu" (idem, p.19). Em outros momentos, as cores intensificam a descrição a ponto de torná-la quase uma figura, um quadro, uma fotografia diante do leitor:

\begin{abstract}
A face aparentemente uniforme da floresta transformava-se a cada momento por raios de sol que filtravam-se através das folhas, revelando um caleidoscópio sempre cambiante de cores, que iam do verde-pálido da samambaia tenra ao brilho quase negro das palmeiras gigantes. (1994, pp. 42-43).
\end{abstract}

A relação entre Ada e seu piano é o ponto central da narrativa. Logo na primeira página do romance, em primeira pessoa e em itálico, o pensamento da personagem inaugura a história, contando ao leitor que ela é incapaz de falar desde os seis anos, que está indo rumo a um casamento arranjado em uma terra desconhecida, e que não se sente muda, por causa de seu piano. Configura-se desde o início sua relação com o piano como a possível expressão de sua voz, extensão metonímica de seu corpo. A música é sua linguagem e é por meio da sensualidade, da emoção e do prazer que ela desperta em Ada que Baines chegará até a pianista.

A cena do reencontro de Ada com seu piano, na praia onde havia sido forçada a deixá-lo, é descrita como um momento de êxtase, beleza, transcendência. Sua estreia musical em território neozelandês é um sucesso, a julgar pela reação de sua plateia: George Baines.

\footnotetext{
George Baines estava magnetizado. Nunca tinha ouvido música assim, tão plenamente voluptuosa; nunca vira ninguém tocar com tão apaixonado enlevo. Ele não conseguia afastar os olhos daquela mulher, aborta no som da música que produzia. Era um momento sublime, de pura beleza, ali na praia, as ondas quebrando na areia e os pássaros marinhos voando em círculos sobre suas cabeças. Ada tocava sem parar, algumas vezes a quatro mãos com Flora, mas a maior parte sozinha, enquanto George Baines olhava e se extasiava. A música era celestial e as mulheres também lhe pareciam sobrenaturais, angelicais. Baines emocionou-se, sentindo que poderia chorar de prazer ante tanta raridade e beleza. (1994, p. 59-60)
} 
A história se desenrola em torno da paixão pela música e da interação singular que Ada cria entre seus sentimentos e os arranjos que extrai de seu piano. A música se torna, ainda que de modo sutil, mais uma instância intermidiática do espesso tecido verbal.

\section{Mídia: o cinema}

Internacionalmente aclamado, $O$ Piano é um filme poético que busca a expressividade máxima dos meios visuais e sonoros, alternando o uso diegético e não diegético da música, com metáforas belamente construídas, deslocamentos, diferentes perspectivas, close-ups e cenas aéreas. Segundo a roteirista e pesquisadora inglesa Jill Nelmes, em Introduction to Film Studies (2012), a estética de O Piano é expressionista: um ponto forte nele é a forma como a direção de Campion explora o jogo de efeitos entre luz e sombra e o contraste claro-escuro que se evidencia, por exemplo, na pele alva de Ada em oposição a suas roupas e chapéu pretos.

Um dos aspectos privilegiados dessa montagem fílmica é o cenário natural e exuberante da Nova Zelândia. A câmera captura imagens da paisagem que se tornam eloquentes e assumem diferentes conotações. Jill Nelmes (2012) alude à mata semi-virgem e fechada como prenúncio da nova realidade que circundará as duas estrangeiras - um mundo inóspito, pouco trilhado e misterioso, cujo vigor e densidade lembram as florestas selvagens dos contos de fada, carregadas de perigos, estranhos seres e potencial erótico. Quando chegam à nova terra, Ada e Flora são surpreendidas por uma tempestade que dificulta a subida pela montanha; o vento agita a vegetação e a lama densa cobre as botas e a barra das volumosas saias europeias.

A natureza também simboliza as diferenças entre os personagens Stewart e Baines. A casa de Stewart, seu mundo imediato, é rodeada de troncos de árvores petrificados, acinzentados, semimortos. A cabana onde mora Baines, cercada por uma abundância de plantas, integra-se ecologicamente à floresta, onde ele se sente à vontade na companhia dos maoris.

A competente equipe cinematográfica que cuida da transposição audiovisual do roteiro - e aqui vale lembrar que Campion reúne seu domínio das palavras a seu talento de diretora - acentua alguns momentos da narrativa, 
tornando-os memoráveis. A imagem do piano, ao longe, na praia, a partir do olhar de Ada, assume status icônico. A força dessa cena se intensifica pela presença da música tema do filme, que intuitivamente nos leva a compreender o elo vital e pulsante que liga a pianista ao instrumento.

Neste ponto, cabe observar a diferença entre as mídias escrita e cinematográfica quanto às técnicas e possibilidades materiais de realização de que cada uma dispõe e à forma como estimulam a percepção sensorial de seus receptores. No papel, a música se integra ao texto de forma sugestiva, apelando à sensibilidade do leitor e a sua capacidade de recriar seu repertório de vivências musicais. No cinema, a música incorpora-se concretamente à linguagem verbo-visual, propiciando aos espectadores uma experiência sonora imediata e cheia de surpresas. A respeito da função da música em O Piano, Nelmes (2012) afirma que o filme é único no modo como vincula as melodias à personagem; o uso diegético da música assume o papel de canal de expressão de emoções e pensamentos que não podem ser exteriorizados pela voz.

Em artigo sobre as funções da música na narrativa cinematográfica, Claudia Gorbman (1987), professora na Universidade de Washington, propõe os princípios básicos para composição, mixagem e edição da música, dentre os quais, a nosso ver, quatro se alternam no decorrer do filme O Piano: 1. significante de emoção, para enfatizar emoções particulares sugeridas na narrativa; 2 . marcação narrativa, para interpretar eventos narrativos; 3. continuidade: para dar continuidade rítmica e formal entre tomadas, em transições entre cenas; e 4. unidade: para auxiliar na construção da unidade narrativa e formal (Baptista; Freire, 2006, p. 746).

Claudia Gorbman, no livro intitulado Jane Campion's The Piano (2000), editado por Harriet Margolis, dedica um ensaio exclusivamente à música do filme em questão, no qual oferece informações valiosas para a compreensão do papel da música na construção da protagonista. Segundo a estudiosa, Campion esboçou seu roteiro (o "hipotexto", de Stam) tendo em mente a habilidade da atriz Holly Hunter como pianista. Esse dado é de especial relevância, pois o fato de a atriz ser ela mesma a intérprete das músicas confere autenticidade à personagem; a câmera focaliza a expressão do rosto e o movimento das mãos e do corpo, que acompanham em verda- 
deira sincronia o andamento, o ritmo, a pulsação da música. O prazer, a preocupação, a irritação ou alegria que a câmera registra nas cenas em que Ada toca piano proporcionam um efeito de realidade que filmes em que os atores simplesmente dramatizam estar tocando um instrumento não conseguem atingir (Gorbman, 2000). Hunter/ Ada incorpora a música de forma a tornar a interpretação crível e envolvente.

Como poderoso elemento fílmico para a construção de sentido, a música forja a aliança entre o que a personagem sente/pensa e a narrativa visual, auxiliando o espectador a acompanhar de perto a vida de uma protagonista incapaz de se comunicar verbalmente:

\footnotetext{
Mas, à medida que o filme avança e que Ada entra em um desespero cada vez mais profundo, ao estar separada de Baines, a música que ela toca se torna menos típica do período histórico [década de 1850]. Essa gradual transição para tons obsessivamente rítmicos, repetitivos e cromáticos é a expressão de seu estado interior. (Gorbman 2000, p. 48) (minha tradução)
}

Outro dado fornecido por Gorbman é que, a despeito de O Piano ter sido aclamado pela crítica de cinema e pelo público, críticos de música qualificaram como decepcionante a escolha da música-tema em termos de sua qualidade musical, considerando-a simplista, anacrônica e invariável. Porém, argumenta a pesquisadora, a opção por um repertório fixo de músicas populares da época daria ao filme um tom mais convencional que não traduziria o estilo próprio de Ada e o fato de sua música ser pessoal, resultado de centenas de horas de prática. Ada não parece tocar a partir de partituras impressas; o que ela toca parece sair "de dentro". É por este motivo que Campion convida Michael Nyman, cujo trabalho anterior com trilhas sonoras admirava, para compor especialmente para O Piano, 19 peças e o tema ou a "alma" do filme, The Heart Asks Pleasure First.

Nyman parte do princípio de que a personagem central não é pianista profissional e que, portanto, suas composições tinham que ter "certa modéstia". Ele também compõe levando em conta o gosto e habilidade de Holly Hunter no piano, ciente de que ela havia ficado um longo intervalo sem praticar. O resultado é que, apesar de simples, quando interpretadas ao piano por Hunter/Ada, as músicas (inclusive as melodias folclóricas 
escocesas) ganham intensidade e assumem os traços de originalidade e excentricidade da personagem.

\section{Discussão}

Um dos momentos mais dramáticos e impactantes da narrativa é aquele em que Stewart, tomado de ciúme ao descobrir que Ada quebrara a promessa de não entrar em contato com Baines, se vinga da esposa.

Esse momento é narrado no Capítulo 10 do romance com uma linguagem vívida e quase visual, que pouco a pouco conduz o leitor ao ponto máximo de tensão. Stewart retira as tábuas que aprisionam Ada e Flora em sua casa, dá seu voto de confiança a sua mulher, que concorda em não procurar o amante. Tão logo ele sai para trabalhar, Ada pede à filha que leve a Baines uma tecla do piano, na qual inscreve uma mensagem de amor. A menina, que estava brincando, obedece muito a contragosto e, no caminho, decide que deve entregar a tecla-mensagem a Stewart.

A reação explosiva do marido prenuncia o que está por vir: "Stewart corria, sem nada ver, dominado pela raiva, conduzido pelo ciúme. $\mathrm{O}$ dia mudara do sol para uma súbita escuridão. Começou a chover, e uma tempestade ribombou, armando-se maligna no horizonte" (1994, p. 178). As palavras de indignação e ódio que ele profere aos gritos alternam-se com atos de brutalidade descritos com precisão cirúrgica:

Ela [Ada] percebeu imediatamente o que tinha acontecido. Levantou-se da mesa, célere, no momento exato em que o machado descia sobre a madeira, cortando o canto do livro. Ada refugiou-se de encontro à parede. Stewart arrancou o machado da mesa, sua expressão alterada, os tendões do pescoço visíveis, saltados.

— Por quê? Eu confiei em você — disse, os dentes trincados. (1994, p. 178)

A passagem assume um tom melodramático que envolve o leitor, agora cúmplice, já que não pode senão prosseguir a leitura. "Flora observava, apavorada demais para intervir, enquanto Stewart arrastava Ada pela lama, até o tronco de cortar lenha. A chuva caía, intermitente e implacável" (1994, p. 179). A narrativa mantém a alta carga emocional, aumentando no leitor a expectativa de um desfecho cruel e trágico. Stewart segura a esposa 
pela roupa, pelos cabelos, arrastando-a até o pedaço de tronco onde coloca a mão direita de Ada e desce o machado com força.

\begin{abstract}
Passou-se um momento - um negro momento de silêncio em que todos e tudo, até os pássaros, pareceram mudos - e então o rosto de Ada transformou-se com a dor [...] levantou-se tentando alguns hesitantes passos através da lama, aí voltou-se para olhar o que ele havia feito, o que havia ficado no tronco. Estava pálida, sua mão expulsando sangue enquanto a apertava, tentando estancar o fluxo. Foi então que viu o que ele fizera; o dedo indicador cortado na raiz continuava pousado sobre o cepo. Ela olhou para o céu, pensando em como teria vindo parar naquele lugar. [...] O rosto acinzentado e imóvel, Ada andava, trôpega, sem ver, tentando reunir toda sua força e dignidade. Ela tropeçou, caiu de joelhos, as duas mãos na frente, na lama, indiferente à dor, e então ergueu-se novamente. Por fim, como um barco que soçobra, mergulhou no pântano, seu vestido inflando ao redor dela, enquanto afundava. (Campion; Pullinger, 1994, p. 180-181)
\end{abstract}

Transposta para o cinema, a cena observa uma sequência semelhante à relatada no romance (e no roteiro), adaptando, com recursos e técnicas próprios, o melodrama da traição de Ada, da desobediência de Flora, da descoberta de Stewart e de sua reação de total descontrole, do confronto com a mulher, do ato castrador de violência e da dor dilacerante e muda de Ada. É certo que romance e filme, no tocante a seu diálogo e fusão, desafiam fronteiras e dialogam entre si; mas, ao se aproximarem, o fazem por meio dos recursos técnicos e artísticos de que dispõem, concretizando manifestações únicas, que a teoria e a prática consagraram como gêneros distintos.

As adaptações do roteiro The Piano Lesson para romance e para filme partilham aspectos da estrutura narrativa, mas cada mídia gera um produto singular em termos de proposta estética e comunicativa. Se o romance $O$ Piano engaja o leitor e estimula sua imaginação por meio da seleção criteriosa e bem pensada de palavras, estruturas, inversões, ritmos marcados pela pontuação, figuras de linguagem, estratégias de ponto de vista, e tantos outros, o filme O Piano comunica-se com o espectador por meio dos recursos próprios à arte cinematográfica (muitos deles incorporados de outras mídias): para incitar a imaginação, explora diretamente a percepção visual e aural, fazendo uso criativo das imagens, da fotografia, da luminosidade, dos planos, do figurino, dos enquadramentos, da trilha sonora, da voz dos 
atores, do silêncio e tantos outros. Entre as duas mídias parece persistir um quê irredutível que as torna únicas, e, por isso mesmo, passíveis de interatividade.

Na produção fílmica, a passagem em que Stewart pune Ada, por haver ela violado o acordo de não procurar Baines, é apresentada ao espectador através de cenas que se alternam entre ritmos rápidos e lentos, gestos em close, sons e palavras, que reiteram o conjunto de emoções exacerbadas que Sam Neill e Holly Hunter dramatizam.

A sequência acontece com pouca interferência das falas. Vê-se Stewart saindo para o trabalho; Ada o vê pela janela e vai até o piano de onde retira uma tecla e grava uma mensagem; ela embrulha cuidadosamente a tecla, que vai entregar a Flora. A menina está brincando ao ar livre e diz não quer levar nada a Baines. A mãe insiste, usando língua de sinais, até a menina concordar. Flora sai cantarolando uma canção escocesa, saltitando pelo caminho de terra úmida, até que, quando toma a trilha para a casa de Baines, decide voltar e pegar a trilha que leva até o local onde Stewart está trabalhando.

O teor da mensagem deixa Stewart fora de si e ele avança em direção à casa, com o machado na mão. A chuva começa a cair, mesclando-se a seu suor. O passo acelerado, quase em corrida, torna-o ofegante, e ele força a passagem pela vegetação que se agita, os troncos escuros, tudo sombrio. Predominam tons escuros de verde azulado, que mancham e cobrem a tela, tornando o ambiente e a cena cinzentos e escurecidos.

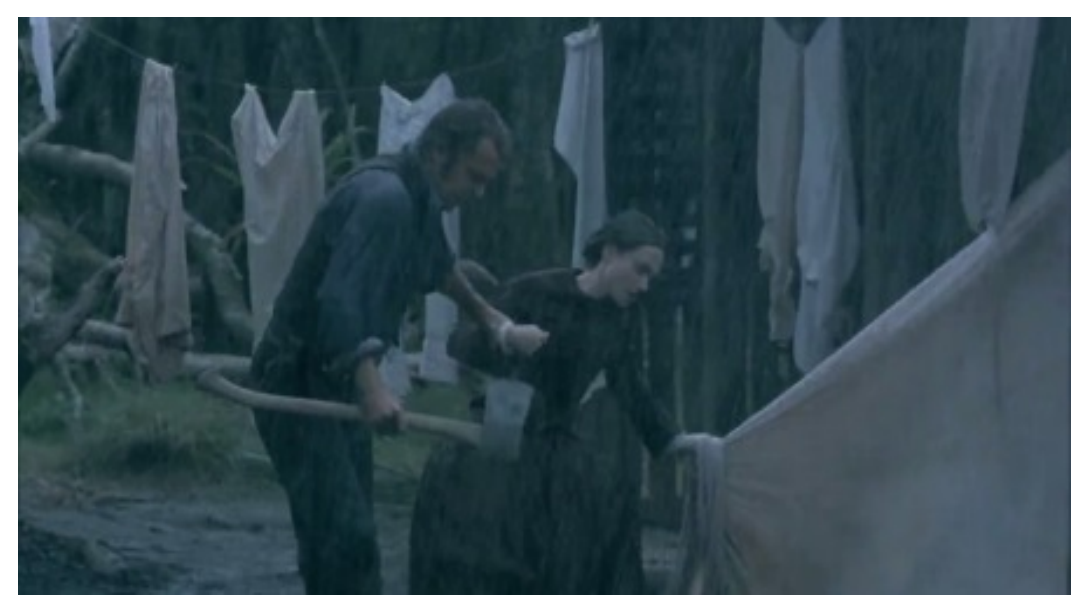




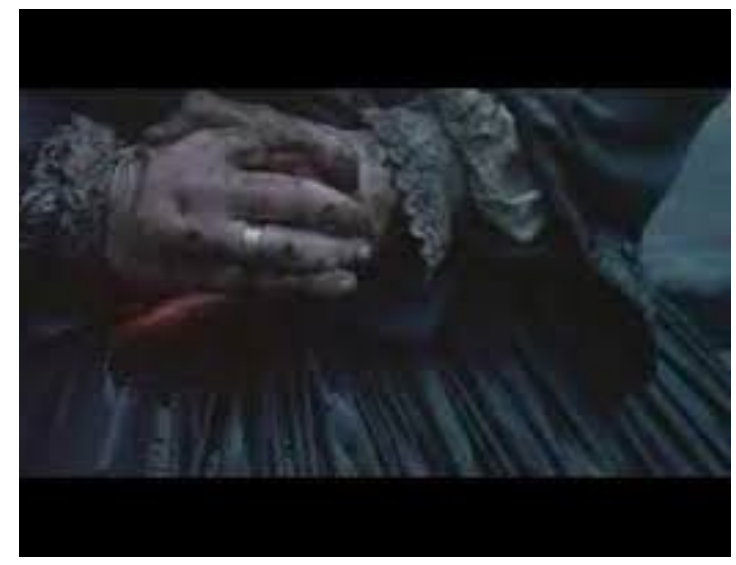

Essa impactante e eloquente sucessão de cenas é ainda intensificada com a presença da música tema. Um piano não diegético entra quando Stewart recebe a tecla do piano gravada com uma mensagem para Baines e desce correndo a colina em fúria, segurando o machado; a música continua obsessivamente quando ele investe contra Ada dentro da casa, arrastando-a para o tronco de cortar lenha e continua a acompanhar Stewart até que ele desfere o golpe fatal: então, a música cessa. O silêncio envolve a protagonista enquanto ela dá alguns passos vagarosos e afunda na lama; o tema retorna, muito mais lento, como se representasse um novo ritmo, subjetivo, próximo à morte do tempo e do corpo.

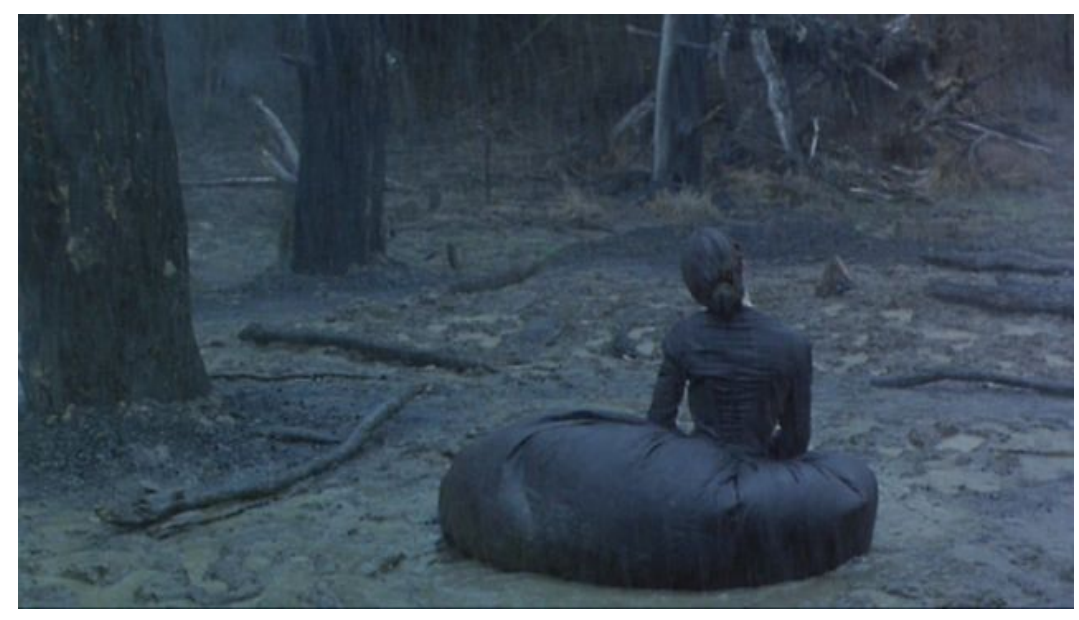


Gorbman observa que a escolha da música tema para a cena da mutilação difere da opção convencional de usar música de orquestra, que tende a evoluir em um crescendo até alcançar seu ápice no momento do clímax dramático. Como explica a estudiosa, o tema executado no piano não é ilustrativo, isto é, não tem um sentido fixo relacionado a um referente estável. Ao contrário, The Heart Asks Pleasure First adquire significado nos contextos em que se insere, atuando como um significante de emoção (Gorbman, 1987). Quando ela aparece na cena em que Ada olha para o piano, distante na praia, ao entardecer, a música parece simbolizar o mais puro sentimento de harmonia da alma, insinuando o carinho sincero por algo que se ama e que relutamos em deixar. Contudo, mais tarde, quando Stewart a procura para feri-la física e moralmente, o tema surge como expressão de luta, agonia e tragédia; quando ele decepa uma "tecla" da mão da pianista, a música é suspensa, em mudo testemunho de horror.

\section{Para concluir}

Nossa reflexão sobre duas mídias (escrita e fílmica) gestadas a partir de um texto dito de partida (o roteiro) apoiou-se no conceito de tradução intersemiótica ou transmutação de Jakobson, na noção de dialogismo intertextual de R. Stam e no conceito de intermidialidade, mais precisamente de transposição ou transformação midiática, postulado por Rajewsky.

O hipotexto que serve de referência para a construção dos hipertextos romance e filme é o roteiro The Piano Lesson - também ele um gênero que abriga diferentes tipos textuais (com ênfase na descrição) e inclui, em seu formato, tanto o argumento-base da narrativa e seus diálogos, como uma série de indicações "externas" de variadas ordens, desde as chamadas rubricas, ou orientações a atores e diretores, as quais especificam gestos, humores, expressões, etc, até instruções para a equipe técnica de montagem relativas à caracterização de cenários, figurino, entradas de voz do narrador, luminosidade, música, posicionamento das câmaras e outros.

Um roteiro - também ele composição híbrida — visa a um pequeno número de leitores, potenciais recriadores, aos quais fornece os elementos-chave para a construção. Dessa forma, podemos pensar no roteiro como um texto aberto, destinado à adaptação ou à transposição midiática, que 
oferece um conjunto de indicações que propiciarão o nascimento de outra linguagem, mídia ou arte.

Hoje, cada vez mais temos conhecimento da heterogeneidade de cada mídia e do diálogo intertextual que praticam entre si. Estamos cientes da crescente permeabilidade das fronteiras intermídias e do intercâmbio e fusão de recursos entre as artes, o que tem resultado no enriquecimento de suas camadas de significação e de suas interrelações. No entanto, é preciso um olhar para estar atento para as singularidades. Para o teórico alemão Claus Clüver, a função da transposição intersemiótica ou intermidiática parece ser justamente "a exploração das possibilidades e das limitações do processo, que deve resultar num reconhecimento das diferenças midiáticas mais do que das semelhanças" (2011, p.19).

Para finalizar, e endossar nossa convicção de não se pode esquecer a diferença, aquilo que resiste à fusão no processo híbrido das relações intermediáticas, recorremos à ponderação esclarecedora de Néstor Canclini: “Uma teoria não ingênua da hibridização é inseparável de uma consciência crítica de seus limites, do que não se deixa, ou não quer ou não pode ser hibridizado" (Canclini apud Machado, 2007, p. 78).

\section{Referências}

AMORIM, Marcel. Da tradução intersemiótica à teoria da adaptação intercultural: estado da arte e perspectivas futuras. In: Itinerários, Araraquara, n. 36, jan./jun. 2013, pp.15-33.

BAPTISTA, André; FREIRE, Sérgio. "As funções da música no cinema segundo Gorbman, Wingstedt e Cook: novos elementos para a composição musical aplicada". XVI Congresso da Associação Nacional de Pesquisa e Pós-Graduação em Música (ANPPOM), Brasília, 2006. Disponível em: http://antigo.anppom.com.br/anais/anaiscongresso_anppom_2006 Acesso em: 14 abr. 2015

CAMPION, Jane; PULLINGER, Kate. The Piano. London: Bloomsbury, 1994. O Piano. Rio de Janeiro: Rocco, 1994.

CLÜVER, Claus. Intermidialidade. In: Pós: revista do programa de pósgraduação em artes da Escola de Belas Artes. Belo Horizonte: EBA/UFMG v. 1, n. 2, 2011, pp. 8-23. Disponível em: 
http://www.eba.ufmg.br/revistapos/index.php/pos/issue/view/2/showToc.

Acesso em: 20 ago. 2015

GORBMAN, Cláudia. Unheard Melodies: Narrative Film Music. Bloomington: Indiana University Press, 1987.

Music in 'The Piano'. In: Jane Campion's The Piano. Edited by Harriet Elaine Margolis. UK: Cambridge University Press, 2000, pp. 42-58.

HOLDERBAUM, Flora Ferreira. A voz-música na intermídia som-palavraperformance. Dissertação apresentada ao Programa de Pós-graduação em Música do Departamento de Artes e Música da Universidade Federal do Paraná, 2014.

Disponível em: dspace.c3sl.ufpr.br:8080/dspace/handle/1884/35799. Acesso em: 21 jul. 2015

JAKOBSON, Roman. JAKOBSON, Roman. Aspectos Lingüísticos da Tradução. In: Linguística e Comunicação. Tradução de Isidoro Blikstein e Joé Paulo Paes. São Paulo: Ed. Cultrix, 1975, pp. 63-72.

MACHADO, Arlindo. Arte e mídia. Rio de Janeiro: Jorge Zahar Ed., 2007.

NELMES, Jill. Study Case: The Piano. In: Introduction to Film Studies. London \& New York: Routledge, 2012.

Disponível em: http:/ / cw.routledge.com/textbooks / 9780415582599/ data/Case\%20study\%20\%20The\%20Piano\%20Jill\%20Nelm es.pdf Acesso em: 10 jul. 2015

PLAZA, Julio. Tradução intersemiótica. São Paulo: Perspectiva; Brasília: CNPq, 1987. Edição de 2008.

RAJEWSKY, Irina. A fronteira em discussão: o status problemático das fronteiras midiáticas no debate contemporâneo sobre intermidialidade. In: Intermidialidade e estudos itinerantes: desafios da arte contemporânea. Tradução de Thaïs Flores Nogueira Diniz, André Soares Vieira. Belo Horizonte: Rona Editora: FALE/UFMG, pp. 51-73, 2012. Disponível em: www.letras.ufmg.br/.../Intermidialidade $\% 20 e \%$ 20Estudos\%20Interartes\% Acesso em: 18 ago. 2015.

STAM, Robert. Beyond Fidelity: The Dialogics of Adaptation. In: Film Adaptation, ed. James Naremore. London: The Athlone Press, 2000, pp. 54-76. Teoria e Prática da Adaptação: da Fidelidade à Intertextualidade. In: Ilha do Desterro. Florianópolis, UFSC, nº 51, jul./ dez., 2006, pp. 19- 53. 
A literatura através do cinema. Tradução de Marie-Anne Kremer e Gláucia Renate Gonçalves. Belo Horizonte: UFMG, 2008.

Resumo: A presente reflexão parte do entendimento de que tradução e adaptação são processos intertextuais que implicam releituras e reescritas de um texto de partida, i.e., de um texto pré-existente. Neste artigo, abordamos o conceito de tradução e adaptação como "práticas de reescrita intertextual" Stam, 2005, p. XX). Nosso propósito é comentar aspectos das adaptações do roteiro Piano Lesson, de Jane Campion, para o livro The Piano: A Novel, por Campion e Kate Pullinger, e para o filme The Piano, dirigido por Campion, a fim de discutir as formas e recursos empregados pelas duas linguagens.

\begin{abstract}
This discussion derives from the understanding that translation and adaptation are intertextual processes involving rereadings and rewritings of a source text (i.e., a pre-existing text). In this article, we discuss the concepts of translation and adaptation as "intertextual rewriting practices" (Stam 2005, XX). Our goal is to examine aspects of the adaptations of Jane Campion's screenplay Piano Lesson into the book The Piano: A Novel, by Campion and Kate Pullinger, and into the film The Piano, directed by Campion, in order to address the methods and resources employed in the two
\end{abstract}

\title{
mediums.
}

